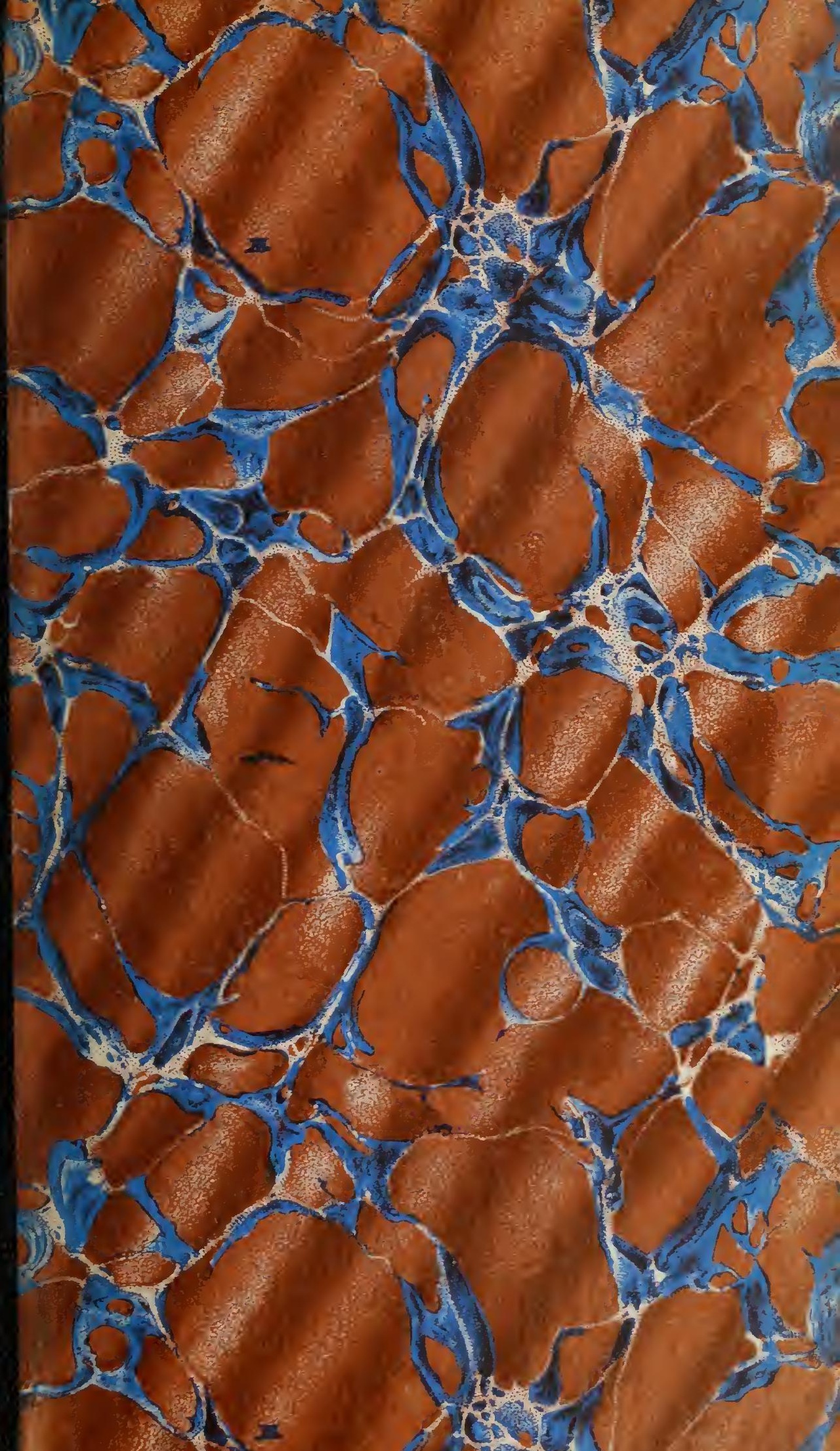




\section{speCiAL}

\section{COLLECCIONS}

DOUGLAS

LIBRARY

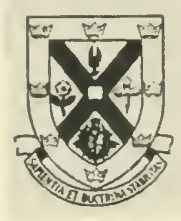

qUEEN'S UNIVERSITY

AT RINGSTON

KINGSTON ONTARIO CANAOA 
i 


\title{
W A Y
}

TO BE

\section{Rich and Refpectable.}

\author{
ADDRESSED TO
}

Men of Small Fortune.

In this PAMPHLET is given, among a variety of other Eltimates or Plans of Living, one thewing that a Gentleman with Economy, refiding in the Country, may, with a few Acres of Land, live as well for Five Hundred Pounds a Year, and make an Appearance in Life equal to thofe who fpend double the Sum, without thofe Advantages.

Stch as are fond of Farming, will here find the Expences attending, and the Profits arifing from, the Cultivation of Land, Feeding of Sheep, \&ic. Sec.

THE SIXTH EDITION.

\section{O N D O N:}

Printed for the A U T H R ; at the Litergre prele; And fold by the Trullers, at No. 14, Red Lion Street,

CLERKENWELL. 
Entered at Stationers jall. 1787. 
Way to be Rich and Refpectable.

\author{
ADDRESSED TO
}

\title{
Men of Small Fortune.
}

THE great degree of luxury to which this

I country has arrived, within a few years, is not only aftonifhing but almoft dreadful to think of. Time was, when thofe articles of indulgence, which now every mechanic aims at the poffeffion of, were enjoyed only by the Baron or Lord of a diftrict. Men were then happy to be the vaffals or dependants of that Lord, and prided themfelves in little but their fubmiffion and allegiance. This was the itate of things during feudal government: but as, on the increafe of trade, riches increafed; men began to feel new wants; they became gradually lefs hardy and roburt, grew effeminate as their property accumulated, and fighed for indulgences they never dreamed of before.-Methods of conveying 
ing thefe indulgences from one part of the kingdom to another were then Atudied; roads were made paffable, and carriages invented.

For many ages coaches were fo great a luxury that none but old families were feen in them; and if they attempted, once in a dozen years, to travel a few miles in one, perhaps, in the courfe of the journey, a whole village with their teams was called in aid, to drag the heavy velicle out of the clay, aud fet it on its wheels again: riding on horfeback being the only means of vifiting a neighbour, beyond the reach of a walk, and that only in the fummer-time. And it is but a very few years fince, that ladies went about, from place to place, upon a pillion. Made roads were then unknown, and fo little defire had the people to fir beyond the bounds of their parin, that even mending them was never thought of.

On the eftablifhment of poits, a general communication was opened between all parts of the kingdom, and people received intelligence of every little improvement that was made: a defire to infpect thofe improvements gave men an eccentric turn; they were eager to fee what was doing at fome diftance from home, and rambled wicle for that purpofe. The inconvenience, and indced impoffibility of travelling, but at cer- 


\section{还ich and Reffectable.}

tain feafons of the year, led the way to the making of roads; making of roads drew thoufands abroad, and a winh to be thought opulent by thofe whom they vifited, led them into luxury of drefs. The homefpun garb then gave way to more coftly attire, and refpectable plainnefs was foon transformed into laughable frippery.

In a few years, refinements took place in manners, and well had it been were they merely refinements; but the misfortune is, they foon fpread into extravagancies, and from being commendable, became objects of cenfure. In the reign of Charles I. luxuries were every where feen; and though the civil wars for fome time fmothered them, they broke out afrefh in the reign of Charles II. Wealth then poured in upon the nation; gentlemen vied with eacl other in the appearance they made; many by thefe means were ruined, eftates changed their poffeffors, a fluctuation of property began, and every fucceeding year, gave birth to frefh wants and new expences. Luxury however had not then gained its prefent footing: it is true, the profligacy of the Capital made fome inroads upon the country; but the inhabitants of the country looked on it with dread and aftonifhment. Some of the nobility and principal gentry, at this time, fpent 
fpent part of their winter in London, but the reft of the year, they lived amongt their tenants with their ufual hofpitality. The expences of this age were confined to the education of their children, to their houfes, their buildings, their furniture, their attendants, and their entertainments; and their tenants and neighbours were confiderably the better for it: the more they circulaced their property within their own eftates, the richer their eftates became, and the more powerful and refpectable they grew. Effeminacy of manners was then feen only in cities; balls and affemblies were fcarcely known, and equipages far from being general.

Matters however refted not here. Things gazed at with aftonifhment quickly grew familiar; the infection of the firft clafs foon fpread among the fecond, and what thefe formerly cenfured, they prefently approved. Gentlemen of fimall eftates began annually to vifit the Capital; they gradually made their vifits longer and longer, till, at laft, it became the fafhion to refide only in the country, when the heat made it intolerable in town. Stage-coaches were eftablifhed, the communication between London and the country became more and more open; a tafte for elegancies fpread itfelf through all ranks and de- 


\section{化ich and Relpectable.}

grees of men, and an equipage was confidered as a neceffary of life.

What is the cafe now? Are things otherwife than they were? No; expences are yet increafing, and we are ftill refining upon luxuries. The feveral cities and large towns of this inland catch the manners of the metropolis, and are vicious and extravagant, in proportion to the wealth and number of their inhabitants. Scarce a town now; of any magnitude, but has its Theatre Royal, its concerts, its balls, and its card-parties. The notions of fplendor and amufement that prevail in the Capital are eagerly adopted; the various changes of the fafhion exactly copied, and the whole manner of life ftudiouny imitated. Flys and machines pafs from city to city; great towns become the winter refidence of thofe, whom nendernefs of fortune will not carry to London, and the country is every where deferted.

If I might prefume to dictate to the world, I would venture to fay, that a man of landed property is never fo refpectable as when refident on his eftate; when improving his lands and enriching his tenants; when his beneficence- may be read in the looks of the poor; when his houfe is open, not with the ftiffinefs of a public day, that tells the neighbourhood he would not be perplexed 
perplexed at another time, but with the hofpitality of an ancient Baron.

Gentlemen of very extenfive property may act as they pleafe; the difipation and expences of the Capital can no other ways injure them than in the opinion of their neighbours; but as to men of fimall fortune, the lefs they fee of London the better. Look round among the families we know, and we can eafily trace the infection of the metropolis; the more they pay their vifits there, and the longer they continue, the more vifible are their follies, and not only their follies, but their failings and their vices. The honett franknefs of the country gentleman is obliterated by the equivocal politenefs of the courtier, and the open fincerity of the good neighbour lort in the artifice and deceit of the man of falhion.

For many years a country 'fquire has been an object of ridicule: but why? No other reafon can be given, but that want of polifh that too often characterizes the fops of the age. If we diveft ourfelves of prejudice, he will not appear in fo contemptible a light: it is true, he may want talte and politenefs, but he may poffefs qualities infinitely fuperior. Honeft unadorned freedom is preferable to ftudied and fafhionable deccit. The country' Jquire lives upon his eftate, fpends 
pends his patrimony among his tenants and his reighbours (which form, as it were, but one family around him), and a fpirit of hofpitality opens his doors to every comer; while the fine gentleman vifits his domain, perhaps, but once in the fummer, ftays there as little as he can help, difdains any familiarity with his neighbours, neglects his grounds, and leaves his tenants at the mercy of his fteward. In fhort, an effeminate life emafculates the fine gentleman, and renders him unfit for every thing but fipping of tea, and dealing the cards; whilft the robuft and manly exercifes of the 'fquire keep him healthy and hardy, and, inured to hunger, danger, and fatigue, enable him, when called upon in the public caufe, to be of real fervice to his country.

But it is to be lamented, that the true country gentleman is feldom to be found. The luxuries and effeminacies of the age have foftened down the hardy roughnefs of former times; and the country, like the capital, is one fcene of diffipation. If there be any œconomy in their expences, it is merely the faving of neceffaries to wafte on fuperfluities: the private gentleman, with three or four hundred pounds a year, muft have his horfes, his dogs, his pictures, his carriages, his parties of pleafure, equally with him of five times his fortune: drefs, thow and en- 
tertainment engrofs his attention; his lands are unimproved; debts accumulate upon him; he mortgages his eftate; and, when he has lived to the end of his fortune, he either puts a dreadful period to his exiftence, or wears out the remainder of his life a beggar.

However alarming this picture may be, it is neverthelefs a juft one. As I take it, the happinefs of life confifts in health, eafe, and competency, which is as much within the reach of a gentleman of three hundred pounds a year, as one of three thoufand. If the articles of living are dearer than they were fome years back (and they certainly are a hundred per cent.), it ought to quicken the induftry of every one, to increafe his income, if poffible, or reduce his expences in proportion to his fortune.

It is not in the power of men, who have the income only of a fmall eftate to fupport them, to encreafe their revenues; but they may decreafe their expences, or lay olit their money to advantage. Frugality and economy have put many upon a footing with men of larger fortunes, and often made them far more refpectable.-Nothing gives fuperiority in life but independency. Whilf we are at the command of another, we are in a ftate of fubordination: it is being maficr of one's felf only, that makes 


\section{Che Taday to be}

$a$ man free; and it is independency that makes him great.

Now, be our fortune as great as it will, we are never independent whilft we are in debt; and can a man be faid to be free, whilft it is in the power of his taylor or his fhoemaker to confine him?

The gentry of England formerly maintained their pre-eminence over the lower rank by their bounty, their munificence, and their hofpicality; but their fplendor and magnificence now is fupported by the credit of their tradefmen; for idly fquandering their patrimony, they could not keep up an appearance equal to their fituation in life, without the affiftance of thofe very men they would affect to defpife. Now, as nothing can create refpect from men but conferring obligations on them, if we examine rightiy where the obligation lies, in the fubject I am upon, I apprehend it will be found upon the gentleman, and that he owes moft to the fhopkeeper who trufts him. The greateft of all diftinctions in civil life is that of debtor and creditor; fo that he who can fay to another, "Pray, my Lord," or "Pray, Sir, pay me " what you owe me," or "return me my own," may fay to him, with equal propriety, "The " great diftinction, Sir, you imagine there is

" between 


\section{ZRiti and Lacipestable.}

"between us is merely fantaftical; for, if I " wear your livery, and am at your Honour's " call, you owe me wages, and I could lend "you where you would be very unwilling to " go;" or " though I wait at your door till you " are pleafed to fee me; till you have paid me " my bill for the coach you ride in, the cloaths " you wear, or perhaps the bread you eat, your "perfon is at my command, and it is in my " power to lock you up." One would almoft think it impofible that a man fhould ever enjoy a quiet hour, who is given to contraet debts, and knows that a creditor has, from the moment in which he refufes or defers payment, a clain upon his honour, his fortune, and his liberty! Does he nor give his creditor an opportunity of faying the wort thing imaginable of him, and without defamation; for inftance, that he is unjuft and difhonourable? Yet fuch is the thoughtlefs and abandoned turn of fome men's minds, that they can live uncter thefe conftant apprehenfions, ttill go on to increafe the caufe of fo much difgrace, and fancy themfelves poffeffed of an extraordinary thare of dignity! In my opinion, there cannot be a more low and fervile condition, than to be afhamed or afraid to fee any one man breathing; and yet he, who is much in clebt, is in that fituation with refpect 


\section{Cbe catap to be}

to all his creditors. The debtor is the creditor's criminal; and all the officers of power and ftate, who make fo great a figure in life, are no other than fo many perfons in authority to make good his charge againft the unjuft dealer. And as human fociety depends upon his having the redrefs the laws allow him, the debtor, as great as he may be (unlefs privileged, and then he is in as abject a ftate, hiding himfelf under the Shelter of the crown), owes his liberty to his tradefinan, as the felon does his life to his fovereign. I would not be thoughe to be thus fevere againft all debtors; for there are circumftances in which honeft men may become liable for debt by fome unforefeen accident, as by becoming fecurity for others, and the like; but I declaim againft fuch as keep up a farce of retinue and grandeur within their houfes, and yet Thrink at the expectation of furly demands at their doors, or about their coaches. Is it not a deplorable cafe, that many families have become methodically in debt from generation to generation? The father mortgages when his fon is very young, and the boy is to marry as foon as at age, to redeem it, and find portions for his fifters; and he, no ways degenerating from the qualifications of his anceftors, hall take up money upon annuities, 


\section{4 inich and Relpectible.}

leave the fame incumbrance upon his firtborn, and continue in the fame way of living, at the expence of his tradefmen. Were perfons of fafnion to hear how freely they are talked of on this account, it would humble them more than they are aware, and make them look little even in their own eyes. "My Lady Spend" thrift's finery," fays one, " is the reafon "why my wife and daughter appear fo long in " the fame gowns." "The furniture of her " houfe is no more hers," fays another, " than " the fcenery of a playhoufe are the property of " the aetrefs." "My Lord Squander's family " has been maintained," fays the butcher and the pouiterer, "at our expence, fince they laft " came from their country feat." "Pox on his "grandeur," fays the taylor, "I'm quite tired " of drefling him; he fhall go naked for me "for the future, if he does not pay me a little "oftener." Surely this is fufficient to deter the rich and the noble from fuch fcandalous practices! Putting the injuftice of the cafe out of the queftion, I appeal to them, as mentiemen, as men holding a degree of rank among their fellow-creatures, whether it is not a fituation worfe than fervility (for lervants eam their living), to owe the greateft part of what they pride themfelves in, to the contributions of perfons fo 
much below them; to be hunted by their creditors; to be obliged to hide themfelves, left they fhould lofe their liberty; and to be eating the food, and wearing the cloaths, of thofe whofe children are crying for bread, and hivering in rags? - If they have brought themfelves to fuch a ftate, as to feel no uneafinefs when they reflect on their embarraffment, and its confequences to others, they are bafe, worthlefs, and degenerate wretches: but if they are uneafy, where is their happinefs? Where is their boafted greatnefs? A miftaken notion, that a reduction in our way of living is difgraceful, has led many a man to his ruin. Retrenching our expences, when we have lived too faft, is a proof of good fenfe; it declares an abliorrence of our follies, and a determination to be in future free. It is highly degrading to make a figure at the expence of others. Villains of every denomination have done it; an honeft man therefore will defpife the thought; and, if his connections have infenfibly led him on, from one expence to another, till he finds himfelf involved, he will purfue the earlieft and readieft means to difcharge his debts and fet himfelf at liberty.

Now, if an infpection into the expences of his houfehold, a prevention of all wafte, an abolition of fuperfuities, and a faving where it 
can be done with propriety, be not fufficient to effect this, the only method he can take is, to contract himfelf into a narrower compafs, and leffen his eftablinment; and then, though he bas loft fome of his fortune, he will not in reality be the poorer. By retrenching his expences, and defcending into a lower fituation, a man may make himfelf rich almoft when he pleafes: for, let his circumftances be never fo nender, he that can farisfy the necefiary occafions of them, and has fomething to fpare, may be confidered as wealthy. I know fome weak people have faid, all the world make the beft appearance they can, and much of tener above their condition in life than below it; and not to do as others do, is a fingularity that tends to one's difcredit; for fuch is the abfurdity in life, that men are rated in worth, according to the appearance they maks. " Keep up appearances," -faid a diffipated poet,

"Kcep up appearances: there lies the ten?

" The world will give thee credit for the reft.".

This idle notion has brought on the deftruction of thoufands. In this luxurious age, wealth is the only object of admiration; and to wear the appearance of wealth, we become expenfive and extravagant in our manner of living. Thus 


\section{Rich and Refpectable.}

we go on, 'till we exhauft the little property we poffers; and when we can keep ourfelves no longer afloat, on what is called Credit, we fink into beggary and contempt.

This filly affectation of a man's wifhing to appear more wealthy than he is, gives him an uneafy mind, and makes him endure all the torments of poverty. They that go to his houfe fee great plenty, but are ferved in a manner that Thews it is all unnatural, and that the mafter's mind is not at home, in the midnt of all his grandeur. And what gives the unhappy man this peevifhnefs of fpirit is, that his eftate is dipped and is eating out with ufury, and yet he has not the heart to fell any part of it to pay his debts. A proud ftomach, at the expence of reftlefs nights, conftant inquietudes, danger of affronts, and a thoufand namelefs inconveniencies, preferves this canker in his fortune, rather than it fhould be faid that he is a man of fewer hundreds a year than he has been commonly efteemed; whereas to pay for, perfonate, and to keep in one's hands a greater eftate than we really have, is, of all others, the moft unpardonable vanity, and muft in the end reduce the perfon who is guilty of it to difhonour: and yet it is impoffible to convince fuch a one, that if he fold as much land as would pay off 
that debt, he would fave four fhillings in the pound, which he gives for the vanity of being reputed the mafter of what he does not poffers.

I know it is urged, as one plea, for keeping up appearances and giving fplendid entertainments, that by fuch means we improve a focial intercourfe among our acquaintance, and have the honour of keeping the beft company: fome men are idle enough to imagine that they thus create a number of friends. Trencher friends 'tis true they create, but this is all, and fuch are not worth the having. When the openhearted has fpent his all upon fuch friends, what do they do?-Defert him; they fmile at his paft folly, and quit him, as the leaves do the trees, at the approach of winter.

I would not be underftood to recommend a clore penurious way of living; on the contrary, I would have every man live well, but live within his income; and if that income is not fufficient to fupport the rank he bears, it is rather a misfortune than a crime, and he will be more an object of pity than of cenfure. If a man can lefien his rank, in fuch a cafe he would be wife to do it. Perfons of little fortune have prudently declined a title; and though men of more exalted rank would find it difficult, thus to hide themfelves from the notice of the world, 


\section{Rich and Reipectable.}

yet if they could, it would be prudent fo to do, and not like beggar'd peers, fuffer their anceftry and their honours to be read merely in their fmiles, their air, or their eye-brows. Our progenitors were fo fenfible that a man's rank thould be laid afide, or fall with his fortune, that in the year 1477, George Nevil, Duke of Bedford, was degraded by Act of Parliament, and his titles taken from him, for not having fufficient fortune to fupport his dignity. It is truly laughable to fee men boafting of their family honours, who have no Thadow of claim to honour but hereditary fucceffion; neither property nor merit. Family honours at beft are but ideal. He who reminds us upon all occafions of his anceftors, puts us upon making comparifons to his own difadvantage, and fometimes to his great difgrace.

None of thefe would care to fee their pedigree of anceftors appear together under the fame characters they bore, when they acted their refpective parts in life. If the genealogy of every family was preferved, there would probably be no man living valued or defpifed on account of his birth; for there is fcarce a beggar in the ftreets, who could not find himfelf lineally defcended from fome great man; nor any one of the higheft title, who would not difcover feveral 
low and indigent perfons among his forefathers; which, however, is no difparagement to the perfon who has merit of his own. In moft of the pedigrees hung up in old manfion-houfes, the lift is begun with a great ftatefman, or foldier in fome honourable commiffion, without taking the leaft notice of the honeft artificer that begot him, or of any of his frugal anceftors before him: they are torn off from the top of the regifter, and we are not left to imagine that the noble founder of the family was ever born of a woman. I could fay a great deal more upon this head, but it is rather wandering from my fubject, that of making our fituation, if poffible, keep pace with our fortune, and that we may not wifh to live beyond our income.

If a man has any office, and has not fufficient fortune to fupport its dignity and expence, he thould immediately refign it; for he can never fuppofe that the ftate depends upon his fingle fervice, and that there are not enough befides himfelf of larger fortunes who are fufficiently qualified for public employment. And when a man has reduced himfelf to private circumfrances, his neceffities will be leffened, and then fewer conveniences will ferve.

He who lives within his income, may be truly called a rich man. It is this that gives the Hol- 


\section{Zich and Refpectable.}

landers the reputation of being wealthy. They never live to the extent of their fortunes; and, of courfe, are able to do a deal of good. A family eftate with them is feldom put up to fale; whereas with us, inheritances are ever at market. A Dutchman contributes as largely and as cheerfully to the exigences of the ftate, or to the erection of a public building, as he would to the repairs of his houfe, or the decoration of his garden.

Many a man lives above his prefent income, and of courfe upon the property of his tradefmen, on the profpect of fome future place, project, or reverfion, that may put him into cafh. This is called living up to expectations, not to poffeffions, and has been the ruin of many tradefmen who have met with no misfortunes in their bufinefs, and has reduced many a man of fortune to poverty, who has never fuffered from repairs, taxes, law-fuits, or other loffes. They who will live above their prefent circumftances, are in great danger of living in a little time much beneath them, or according to the proverb, "The man who lives by hope, will " die by hunger." Depending upon contingent futurities, occafions romantic generofity, fenfelefs oftentation, and generally ends in beggary and ruin. 
But the good œconomift contracts his defires to his prefent condition, and whatever may be his expectations, lives within the compafs of what he actually poffeffes; he never facrifices his fortune to fools, to knaves, or Hatterers, but wifely hufbands his property, chufing rather to depend upon his own ftock, than the friendnip or good fervices of others. He cannot endure thofe who covet the wealth of other men, at the fame time that they fquander away their own; nor thole who had rather fee their children ftarve like gentlemen, than thrive and grow rich in 2 profeffion or trade that is beneath their rank.

To be refpectable, it is not neceffary to live in a certain line of life.-Every man may be confidered as the centre of a circle; fome of a larger, fome of a fmaller; and, in this light, he is of greater or of lefs importance, according to the character he bears. - A man thould give dignity to his fituation, not his fituation to bim.-He who has feweft wants, and is moft able to live within himfelf, is not only the happieft, but the richeit man; and if he does not abound in what the world calls Wealth, he does in Independency. Though he may not be a Peer of his own country, he is a Lord of the creation; may fill his ftation equal to the firt of men; and look down with pity and contempt on the tinfel- 


\section{Rich and Rerpectable.}

led fycophant, though covered with an ermined robe, and parading with a ducal coronet.

I will allow, it is rather mortifying to fee a neighbour, of lefs pretenfions than ourfelves, living in a degree of fplendour which we cannot reach. If his fortune be large enough to admit of it, it is well; if not, he is an object of contempt. But, be it as it may, whilft we have fufficient to command the neceffaries and indulgencies of life (wanting the fuperfluities), and do abfolutely enjoy them, we are in a fituation equal to any man; and if we keep but a pair of horfes, and pay for that pair, we are far more refpectable in the eyes of fenfible people, than he who is drawn in a coach and fix, but his gate everlaftingly crowded with importunate creditors.

Perfons with circumfcribed fortunes, or whofe family encreafes upon them, would do well to retrench their expences in time; or retire from towns, and lay out their money with economy. It is wonderful to think what an appearance in life a perfon may make for a little money, who refides wholly in the country, and makes the moft of what he poffeffes. I fpeak not to perfons in trade, as the fcheme may be impracticable with them, but to gentlemen of fimall fortune, who, in a rural retreat, with a few acres 
of land, may live as well on three or four huindred pounds a year, as many. do on three times the fum. The occupier of a middling farm enjoys all the neceffaries and conveniencies of life, and many of its fuperfluities. Where thall we meet with better health, than where temperance and exercife enliven the mind, invigorate the body, and give a conftant flow of fpirits? A country life is commonly a cheerful one; we there meet few of thofe rubs that embitter the hours of other men, and are the too conftant at-. tendants on ambition and vanity. It is there only that true happinefs and independency can be found; where honefty and the beft of manners mark the man; and where employment exempts from the ill effects of luxury. A new mode of living may at firft be a little aukward; but the retirement of a year or two will produce fuch heart-felt fatisfaction, as will convince the perfon retiring, it was the beft ftep he ever took in his life.

The following then is an eftimate, whereby a gentleman, with a wife, four children, and five fervants, living in the country, may, with frugality, fave 25001 . in the courfe of twenty years, keep two of his children at a boarding-fchool, drink wine every day at his table, keep a carriage and four horfes, and make an appearance equal 


\section{Rich and Refpritable.}

equal to a man in town who fpends 8001 . a year, for lefs than 500 . as may be feen by comparing this eftimate with that further on of the fame family living in London; and may with the further addition of a fmall farm, live equally well for confiderably lefs.

No. I.

\section{The familp Eftimate.}

Annually.

E. s. d.

Rent of a houfe, with about 35 acres of land* $60 \circ 0$

Taxes and tythest, about - $\quad-\quad-\quad 1800$

Bread, from the farm. See the Farming ERi-

mate, No. 2. page 30.

Butter, from the farm. See the Cow-Efimate,

No. 5 . page ${ }_{3} 8$.

Cheere, ditto. See No. 5 .

Milk and cggs, ditto. See ditto.

Flour, accounted for with the bread, No. 2 .

\section{Carried forward $\overline{7800}$}

* Of thefe 35 acres, about 22 thould be grafs. If fo much pafture land cannot be got, fhift muft be made, by laying down land with artificial graffes, fuch as clover, lucerne, faintfoin, \&c. The additional produce of which will fufficiently attone for the expences attending them. Many houfes may be procured for this price, and genteel ones, even within 20 miles of London; if further off, for much lefs.".

† Suppofing the houfe and land rated at 401. a year, and the houfe to pay for 20 windows. I allow 2s. per acre for tythe, but nothing for the highway rate, which is $\mathrm{Il} .7 \mathrm{~s}$. per annum, as the horfes may do the ftatute duty. 


\section{Annualiy.}

E. s. d.

Brought on $7^{8} \circ \quad \circ$

Meat and fin. See the Meat-Eftimate, No. 3 ,

34 .

$16 \quad 5 \quad 0$

Poultry, from the farm.

Salt, vinegar, muftard, oil, and fpices, per week, is. 7 d.

Vegetables and fruit from the garden*.

Small beer, 2 gallons per day, which, brewed at home, and reckoned at $5 \mathrm{~d}$. per gallon, will allow fufficient ale for the mafter's table, \&ic. without any additional charge, that is 5s. rod. per week, ort - - $\quad \begin{array}{lll}15 & 3 & 4\end{array}$ Tea 2s. per week, or - $\quad-\quad 540$ Sugar for all purpofes, 2s. 6d. per week, or - 6100 Candles, 5 lb. per week, at 8 s. per dozen $\S$ 3s. 4 d. fer week 424 .

\section{Carried forward}

* I have not reckoned feeds, as the garden will produce thefe.

+ In this eftimate a quarter of malt is allowed to 76 gallons of fmall-beer, and $3^{6}$ gallons of ale. The copper heated with furze, or heath, cut from the neighbouring common, or wood off the farm.

\$ Mould and common candles may be bought together. at the price of common ones.

A pair of wax candles in the parlour occafionally, will not make much more then $20 s$. a year difference in the expence, they burning double the time of tallow. 


\title{
Rich and lRecpectable.
}

\author{
Annually. \\ L. s. $d$. \\ Brought on 13360
}

Coals, 8 chaldrons per year, laid in at 11 . 14s.

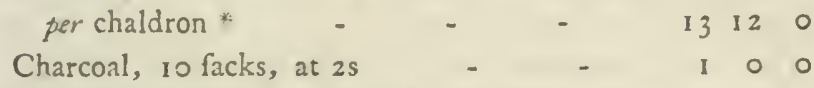

Soap, ftarch, blue, and occafional affifance for wafhing five perfons, 7 s. per week $t \quad 1840$

Whiting, fullers earth, \&cc. 2 d. per week $\ddagger$ or $0 \quad 88$

Wine, punch, \&c. $\|$ - $\quad$ - 13160

Threads, tapes, and all forts of haberdalhery,

15. 6d. per week, or - - $\quad 3180$

Powder, pomatum, blacking, \&c. $\$ 6 \mathrm{~d}$ per week 160

Repair of furniture, earthen ware, \&c. 2s. 6d. por 6 10 o Wages of a man fervant, to act in the capacity of coachman, and to manage the farm - 900 Livery for ditto, to be worn occafionally - 300

\section{Carried forward 20408}

* Thefe must be fetched from the wharf by your own horfes, and the copper muft be daily heated with furze, or heath, which may be cut on the neighbouring common. See the Farming Eftimate, No. 2.

+ The two men to be wafhed out at their own expence.

I Sand, brick-duft, wood to light fires, \&c. are not reckoned, as thefe may be procured in the country without money.

\| Wine, allowing five bottles a week, half of it Port wine, half made wine. Port wine, if a pipe, is bought between two or three friends, and bottled at home, will not colt the buyer more than 1s. $5 \mathrm{~d}$. fer bottle; the made wine half the price, together, 5s. $3 \mathrm{~d}$. three-farthings. What is faved in wine, may be expended in brandy or rum.

$\$$ The mafter and miftrefs muft each drefs their own ha:r. 


\section{Annually. \\ f. s. $d$. \\ Brought on $204 \quad 8$}

Wages of a man fervant, to act in the capacity of gardener 9 and footman

Livery for ditto, to be worn occafionally when waiting at table, or following the carriage -400

Tax on men

Two children kept a fchool, 20l. each

Extra expences attending them, as breaking up, being at home in the holidays, pocketmoney, \&c.

Cloaths for four children (the mother's caft cloaths to be made up occafionally) - $24 \quad 0 \quad 0$

Cloaths for the mafter, with pocket expences $35 \circ \circ$ Ditto for the miftrefs, with ditto - 2500 Apothecary engaged by the year, (no bill fent in) $4 \quad 0 \quad 0$

\section{Carricd forward}

355108

Tा The following book will affift upon this bufinefs, price One Shilling, pafted in marble paper, and not bigger than a pocket almanack, fold by R. BALDWIN, in Paternoft-row, viz. the Garden-Companion for gentlemen and ladies; or, a Calcnder, pointing out what hould be done every month, in the green-houfe, flower, fruit, and kitchen garden: with the proper feafons for fowing, planting, \&c. (with the time when the produce may be expected), fo as to have a regular fucceffion of flowers and vegetables throughout the ycar. To which are added, a complete lift of the flowers and fhrubs that blow each month. With fome curious obfervations. With the help of this book, any country fervant may be inftructed to lcok after a fmall piecc of 


\section{IRich and Reipectable.}

Annually.

E. e. $d$.

Brought on $\quad 35510 \quad 8$

Boy; no livery, but cloathed from his mafter's old wardrobe *

The wages of two maids $t+\ldots$

Duty of a four-wheeled carriage $\quad$ - 70 .

Wear and tear of ditto $\ddagger$, and harnefs, for even money

There muft be laid up, one year with another, for 20 years, in order to leave each child and a widow, if there hould be one, 5001 . each

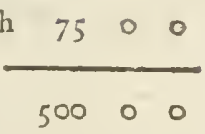

ground at a very little expence; make that ground go a great way, and fupply the table with every thing in feafon. The ladies alfo are here inftructed how to difpofe their flowers to the beft advantage, and to procure a general bloom throughout the year.

* This boy to drive the plough occafionally, or ride and drive when the carriage is ufed as a poft chaife, or to fend on meffages.

+ They may be had for much lefs, at a diftance from London.

I By applying to fome coach-makers, you may change your fet of wheels every year for a ftrong fecond-hand fet, at 1 l. the fet, which will reduce the expences of this article. A good fahionable fecond-hand carriage may be frequently met with for about 20l. which, when frefh painted, at about the expence of 61. will look as well as new. 


\section{Dbiervation.}

It may not be unneceffary to remark, that 15 or 20 per cent. may be faved by paying ready money for what we buy; befides preventing things being charged the family never had.Buy your grocery and fuch things, as country thopkeepers have from London, always in London; and fuch things as they purchafe at diftance from town, endeavour to get at the firft hand in the country.

No. II.

\section{The Jarming= Eftimate.}

Acres.

£. s. d.

I3-Of grafs for horfes. See the horfe-eftimate, No. 4. Nine acres of this are to be laid up for hay. The expence of making and thatching, with the affiftance of your own men and horfes, will be about 5 s. per acre 9-Of grafs for cows. See the cow-eftimate, 250 No. 5. Four acres of this are to be laid up for hay: the expence, as above, 5 s. per acre

8-Of oats will yield about 36 quarters, of of which the four horfes will confume 17 qrs. 4 bufhels See the horfe-eftimate, No. 4 . 17 2rs. 4 buhels For poultry and pigs 13 grs. 4 bufhels For feed to re-crop the ground 


\section{lRicb and Refuectable.}

Acres.

30
Brought on

f. s. $d$.

The expences attending this will be as follow. L. s. $d$.

Mowing

0120

Getting in, about

Threh. 36 qrs. at $1 s, 3$ d.

z-Of wheat, producing 40 bufhels, 8 gallons

meafure, will furnith a family of 9 perfons with flour and bread, at a quartern loaf each per week, and leave $\xi$ bufhels of grain to re-crop the land. The expence attending it will be* as follows :

\section{Aires.}

Weeding - - 050

Reaping - - - 100

Threfhing - - - 0126

Getting in - - - 000

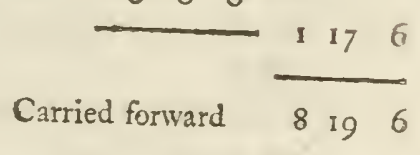

- The corn muft be ground and fifted at home with 2 hand-mill, \&c. the bran will then help to keep the hogs. Yeaft is not reckoned in the article of bread, there being methods to preferve yeaft; or the yeaft from the brewings may be fold, which will buy yeaft when wanted. To preferve yeaft, fpread it on the outfide of a handbowl laying it in the fun, or before the fire, and as it drys put on more, till you can fcrape it off about the thicknefs of a thick pafte, then fpread it on coarfe brown paper, and place it in the fun till dry, and keep it fo. 
Acres.

32

\section{Brought on}

-Of beans, will produce about 7 quarters 4 bufhels, of which it will take to fatten twelve porkers, about I bufhel and a half

- each qr. bufh.

35

\section{4}

- Four bacon hogs, at I quarter each, 40

Seed to re-crop the land - 10

\section{4}

The expences attending the crop will be,

$\begin{array}{llrrr} & & \text { f. s. } & d . \\ \text { Setting } & - & 0 & 15 & 0 \\ \text { Hoeing twice } & - & 1 & 8 & 0 \\ \text { Cutting } & - & 0 & 10 & 0 \\ \text { Threlhing } & - & 0 & 11 & 3\end{array}$

Cutting $45^{\circ}$ faggots of furze, at 3 s. per hundred, for heating the oven twice a week

Cutting 1460 faggots of furze for heating the copper, daily*

Extra expences on four horfes. See the horfe-eftimate, No. 4 .

\section{Carried forward}

* Four faggots will heat either the oven or the copper. The expence attending this article may be faved, as the men fervants may cut the furze at leifure times. The farming-man fhould underitand all kinds of hulbandry, hedging, thatching, \&c. \&c. Thus many of the expences charged might be faved. 


\section{ZRich ano Rerpectable:}

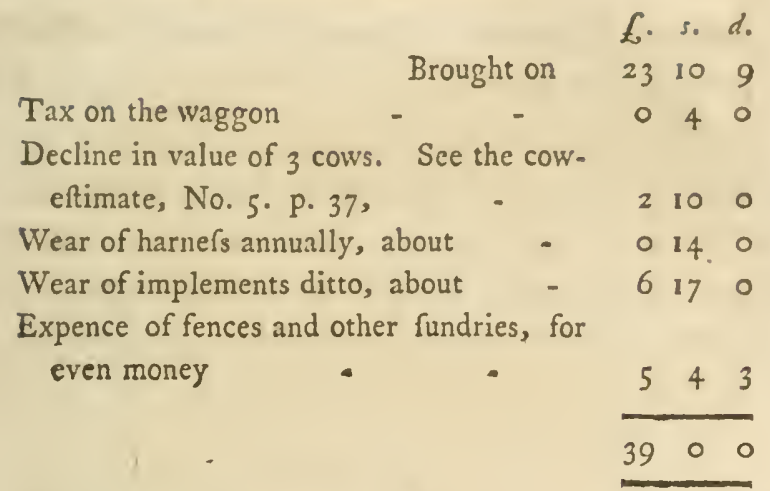

\section{Dbretbations.}

N. B. The crops on the land fhould be changed every year; but this will not alter the real produce.

In cultivating thefe 35 acres of land, the horfes will be employed only about 52 days in the year, which, on an average, is only one day in the week: of courfe, your farming fervant will often be at liberty to threfh your corn, and do many other things: this will fave much of the money I have charged for labour.

I have allowed a fourth horfe in this eftimate, as, fhould the gentleman be fond of riding, he may keep one for that purpofe. The other three I would recommend fhould match in colour and fize, and Thould have nag-tails; as, hould one fall lame, another is ready to fupply its place; befides, 
befides, they may occafionally be ufed as faddlehorfes; or were the whole four to match, with a very little extra-expence in the harnefs, and an additional jacket to lay by, they might all be put to the carriage at times. If one or two of them were mares, a perfon might then breed his own horfes, which would be alfo a faving.

No. III.

\section{Ufe 9 geat= Leftimate.}

Twelve porkers fhould be killed yearly $t_{\text {, that }}$ is, about one a-month, and four hogs for bacon, thus,

Twelve poikers, at 7 Aone each, or $56 l b$, give of $l b$. meat - - - - - 672

Four horgs * for bacon, at 25 ftone each, or $200 \mathrm{lb}$. give - . - . 800

1472

* One fow is fufficient to fupply the family with fixteen pigs yearly.

+ If porkers are conftantly kept on fkimmed milk, they will require no meal to fatten them, if killed under 12 ftone each. Here alfo will be a faving. In cold weather, they fhould lie warm and half a pint of tick beans given to each daily, will warm their infides and keep their coats fine. Currying them occafionally, and waning them with foap-fuds helps their growth. 


\section{理ich and Rerpectable.}

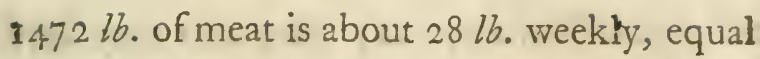
to four days provifion for 9 perfons, and $\dagger$

Fowls, ducks, turkeys, pigeons, and geefe, will give the fifth day's provifion for the fame number.

The expence of the above is included in the farm. All that is neceffary then to be paid for meat, is the provifion of two days: thus

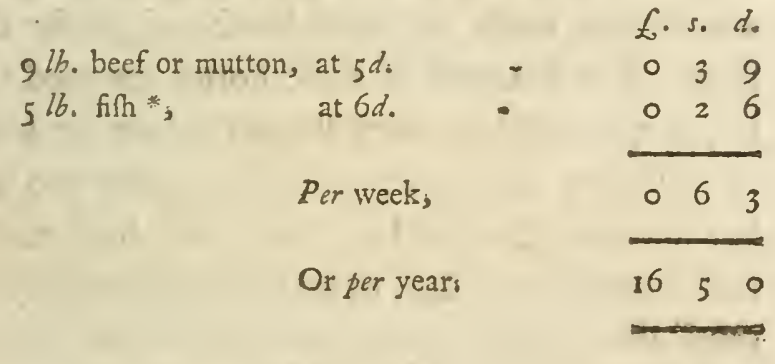

\section{No. IV. \\ 公be borle=tertimate。}

Horfes may be turned out to grafs from about May 20 to October 20, they then fhould be taken into the ftable and ftraw-fed, with corn,

t Left living on fwine's fien four days in a weck fhould be thought improper, it may be obferved, that your butcher will occafionally take a fide of pork, and give other meat in exchange : thus you nced eat pork only two days in the week, and the other two, bacon or ham with poultry.

* Dried falt-fifh, bought of the wholefale dealers in Thames Street, will not coft more than 3 d. per 16 . which will allow more to be paid for frefh fin : befides if near a river, fome kinds of fin may be caught occafionally. 
till about February 20; after this they fhould be fed with hay and corn till May 20 again.

Now, it will require of grafs to feed four horfes through the fummer, with the addition of latter-math and turning into ftubble, four acres. When fed with hay, each horfe will eat about five truffes per week; but I allow fix truffes to afford for hay cut into chaff; this amounts to about two loads for each horfe; eight for the four. But if a pair of thefe horfes are ufed often in the carriage, they fhould never be kept upon ftraw; of courfe, while the other two are fed on ftraw, thefe will eat about five load and a half more of hay; this, with the eight loads reckoned above, will be the produce of nine acres; and this, added to the four acres for fummerfeed, makes the thirteen acres.

I allow each horfe half a peck of oats a day, from October 20 to May 20; that is, three quarters, two bufhels, one peck, which, for the four, is about thirteen quarters; but it may be neceffary to give the carriage horfes the fame quantity all the fummer, which, in the whole, confumes feventeen quarters and a half. The other two horfes need no corn in the fummer, unlefs very hard worked.

N. B. To fave grafs and oats, green clover might be given to horfes in the ftable, till near the 


\section{lRich and Refpectable.}

the middle of Oetober: for while they feed on this, corn is not neceffary.

Horfes thould have as much chaff as they will eat. Befides the chaff of the corn, give each a bufhel of cut chaff daily (hay and ftraw mixed), which will colt a half-penny fer bufhel cutting, and that for the time he is in the ftable will be 210 bufhels, \&c.

Ł. $\circ 889$

Shoeing, once in fix weeks, at 1s. 10. per fet; the price paid by farmers, - - 0148

Phyfic, per even money * - - 067

Decline in value of four horfes annually $6 \circ 0$

Tax on two horfes - $\quad-\quad 100$

E. 8 10 $\circ$

No. V.

\section{The Cow: Eeftimate.}

Suppofing a cow to be dry three months in the year, during which time the may be fed upon ftraw, there will require only nine months good feed. Now, one acre and a half of grafs will feed her well from the time you lay your paftures up for hay; fuppofe from the middle

* Your fervant fhould be able to bleed, and as to phy. fic, the Gentleman's Pocket-Farrier, price is. fold by R. BALDWIn, Paternofter-row, London, will direct how to cure an ailing horfe, at even a lefs expence than this: every remedy in that book I have proved experimentally efficacious. Note, it is fo fmall as to lie in a pocket book, and zeaches you how to treat a horfe, if ill upon the road. 
of April to the middle of October (fix months), with the occafionally turning them on the common and into the ftubbles. The fpring grafs of thofe pafture, before laid up for hay, will keep her from the middle of February to the middle of April (ore month), fo that there are but two months to feed her on hay; and the will, in three months allowing a little for wafte, eat about two loads, that is at the rate of $40 \mathrm{lb}$. per day.

Thus the three cows will eat fix loads, the produce of

And alfo the grafs in fummer of

4 Acres.
4 and a half
8 and a half

A cow, with this keeping, will yield milk and cream for the family, and, on an average, about $\mathbf{3 2 l 6}$. of butter, and $215 \mathrm{lb}$. of cheefe, but in order to this they muft be young cows.

Three cows then will yield annually $396 \mathrm{lb}$. or about $7 \mathrm{lb}$. and a half per week, enough for the family.

Alfo $645 \mathrm{lb}$. of cheefe annually, that is about $12 \mathrm{ll}$. per week, enough for the family.

The fkimmed milk will go a great way towards keeping the pigs (nay, a pig will fatten on fkimmed milk alone, if it has as much as it can drink); and three calves annually will ferve to meet other little expences not thought of.-

Care 


\section{ZRich and iRequectable.}

Care muft be taken to have two of thefe cows always in milk.

The decline in value of thefe cows will be an-

$$
\text { L. s. d. }
$$

nually, about

2100

\section{Gn Eftimate}

Of the expences of the fame family, fuppofing them to live in London, equally well only, and every article to be purchafed.

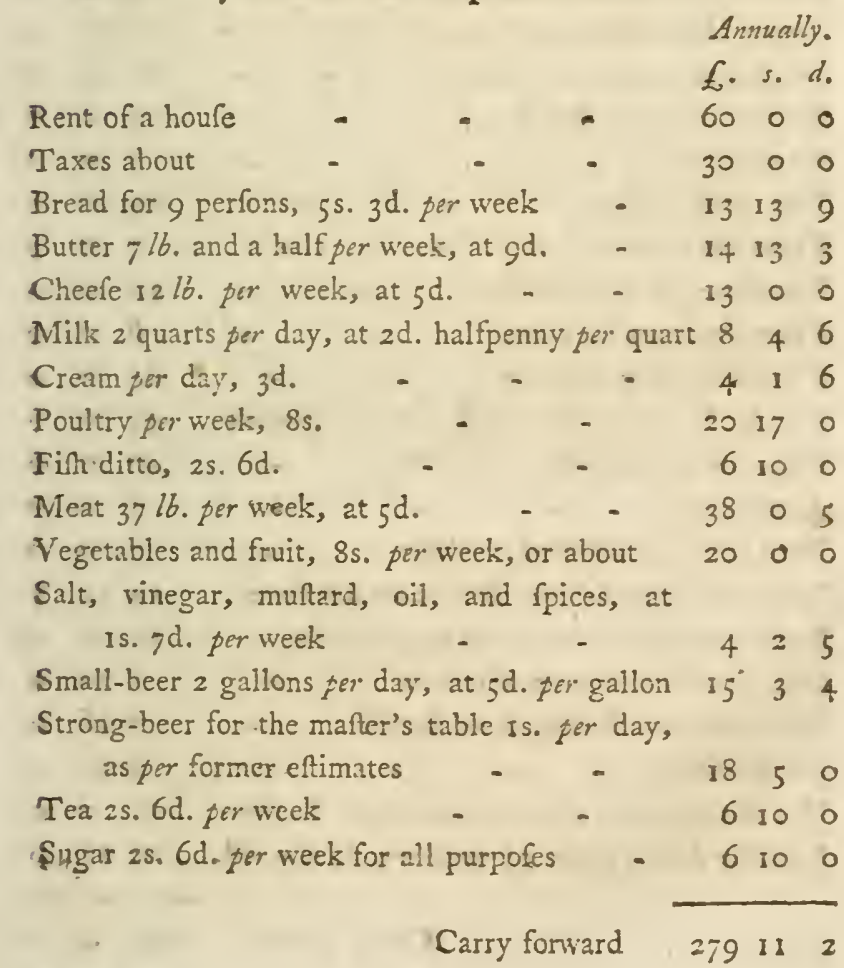


Candles, as in the other eftimate - $\quad 9194$

Coals ditto, 12 chaldrons, at 11. 16s. - 21120

Charcoal, 10 facks, at $3^{\text {s. }}$ - $\quad 1100$

Soap, \&c. and walhing dearer in town $\quad 13 \circ 0$

Whiting, fullers-earth, fand, brick-duft, and

wood, 8d. per week - - 1149

Wine, punch, \&c. - $\quad 1316 \circ$

Haberdafhery 1s. gd. perweek - - 4110

Powder, pomatum, blacking, 6d. perweek . 160

Repair of furniture, \&c. 3s. per week $\quad \begin{array}{lll}7 & 16 & 3\end{array}$

Coachman's wages and livery - $\quad 2800$

Footman's wages and livery - $\quad 2400$

Boys wages - - $\quad 500$

Two maids wages $\quad-\quad 1400$

Taxes for fervants - $\quad 5 \quad 500$

Schooling for two children - 4000

Extra expences for ditto - $\quad-600$

Cloaths for four children $\quad$ - . $\quad 2400$

Cloaths for the mafter, with pocket expences 4500

Ditto for the miftrefs, with ditto - 4000

Apothecary - - $\quad 400$

Duty of a four-wheeled carriage $\quad 7 \quad 0 \quad 0$

Wear and tear of ditto, double on the ftones $11 \quad 12 \quad 8$

Rent of a ftable in town for three horfes 1000

Oil, greafe, and wear of combs $\quad 1100$

Blackimith for thoeing three horfes $\quad 2160$

Farrier about - . $\quad 1100$

Hay for 3 horfes, about 12 loads, at 31 10s. 4200

Oats for ditto, about 34 quarters, at $17 \mathrm{~s} .6 \mathrm{~d} .29150$

Carry forward $696 \quad$ a 


\section{Rith and XRepectable.}

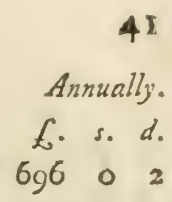

Straiv about four truffes per week, at 25 s. per

$$
\text { load }
$$

Decline in value of the horfes, about

Wear of faddle, \&c. about

Taxes on three horfes

1800

To be laid by annually, as in the other eftimate

$\circ 106$

I $10 \quad 0$

7500

Expences of the fame family living in the

country Difference $\quad-\frac{50000}{298 \text { 1 } 8}$

Befides, in this Town-eftimate there are but three horfes kept; whereas in the country we admit of four, and there are alfo a variety of other comforts, as living in a better houfe for the money, a pleafurable garden, and every other thing in plenty, as vegetables, fruit, game, river filh, poultry cream, \&c. \&c. In this Towneftimate I fuppofe a degree of economy which few people attend to, or, inftead of 7981. the Town-eftimate would be confiderably greater. 
TF a gentleman, by way of amufement, or lefI fening his expences, will add about fifty acres of land more to his thirty-five, he may, with the fame number of fervants, excepting a little affiftance at harveft, reap the following advantages, with this difference only, that it will require a little more of his own attention, and leave his men and horfes lefs at leifure to wait upon him. He muft then fend the produce of his farm to market, and inftead of keeping a horfe merely for the faddle, he muft admit him to draw occafionally: but even here, he may have his horfes for his pleafure, on an average, two or three days in the week.

Thefe fifty acres I will fuppofe to be arable, and as land will produce more one year than another, I will give a courfe of crops for feven years, and thew the annual profits on an average. The courfe then thall be, fuppofing the ground to be tolerable good;
I Turneps .3 Barley
5 Clover
7 Oats
2 Wheat
4 Clover
6 Beans

Although it will be neceffary to have fome of cach kind every year, the amount, at the year's end, with good management, will be the fame.

1. TUR- 


\section{Rich and iReipectable.}

I. TURNEPS.

The natural expences in the firft courfe will be as follows:

\section{Expences.}

Seed, $2 l b$. per acre, at $6 \mathrm{~d}$. per 16.

Hoeing twice, at 10s. per acre

Rent, tythe and taxes, 25s. per acre

Extra tear and wear, fencing, \&cc.

E. s. $d$.

2120

2500

62100

800

980

Produce.

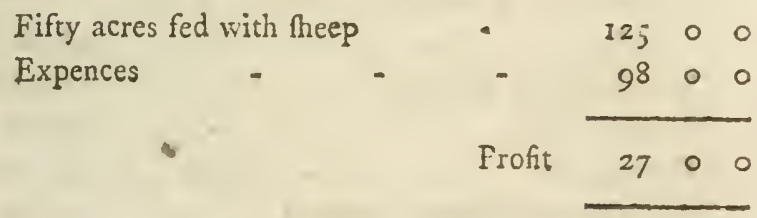

2. WHEAT.

Expences.

L. s. $d$.

Seed 2 bufhel and a half per acre, at 5s, 64. $34 \quad 7 \quad 0$

Weeding, 5s, per acre - 1210

Reaping, ros. a - $23 \circ 0$

Affiftance to get it in - - 30 -

Threfhing 25 loads, at 3 s. per quarter and

binding ftraw - 18150

Rent, tythes, \&c. - $\quad 62100$

Wear and tear, and fencing, \&c. $\quad 8 \circ \circ$ 
Produce.

Fifty acres, at 2 quarters and half, at $\mathrm{nl}$.

per load

One luundred load of ftraw 27500 10000

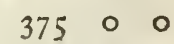

Expences

Profit

210180

3. BARLEY, and Clover fown amongt it。 Expences.

Seed-barley, 4 buhel, per acre, at 4 s. per bufhel

Weeding, 5s. per acre $4^{\circ} \circ 0$

Mowing, 2s. 12100

Raking, 2s.

Additional affiftance to houfe it

Threhing 225 quarters, at 2s. per quarter

Rent, tythes

Clover feed, 10lb. per acre

Wear and tear, fencing, \&cc.

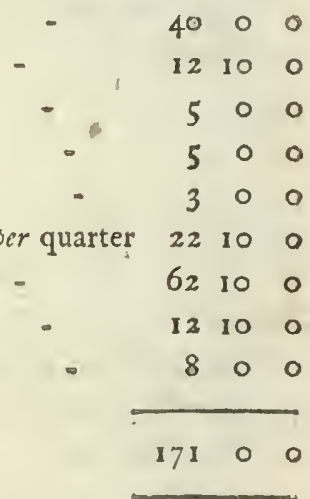

Produce.

Fifty acres, producing 4 quarters and 2 half per acre; 225 qre. at $32 s$. $\begin{array}{llll}350 & 0 & 0\end{array}$ Expences 17100

Profit $189 \circ 0$ 


\section{犆icb anto lRetuectable.}

4. 5. Cloverr.

Espen:es.

Mowing, aț 2s. 6d. per acre

Making and Atacking, 5s. ditto

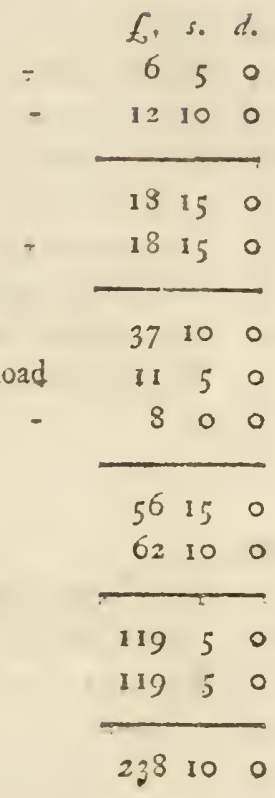

Eroduce.

Binding 150 loads, at $1 s .6 \mathrm{~d}$. per load

Wear and tear, fencing, \&c.

Rent, tythes, and taxes

$=\quad+\quad 18150$

Ditto the fecend crop

37100

800

Ditto the fecond year

$$
\text { - } 11950
$$

Fifty acres, at the two crops, about 3 loads per acre, at 40 s. per load

30000

Fifty acres after-grafs, fed by cattle, at 70s. per acre

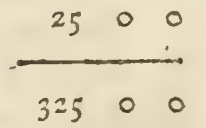

Ditto the fecond year

$\frac{32500}{65000}$

Expences two years

$23810 \quad 0$

$$
\text { Prof.t }
$$

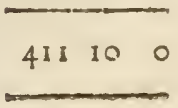




\section{Beans.}

Expences.

$\begin{array}{rrr}\text { E. s. } & d . \\ 20 & 0 & 0 \\ 12 & 10 & 0 \\ 30 & 0 & 0 \\ 12 & 10 & 0 \\ -\quad 3 & 0 & 0 \\ -\quad & 5 & 6 \\ 62 & 10 & 0 \\ 8 & 0 & 0 \\ -\quad 15915 & 0\end{array}$

Produce,

Fifty acres, producing three quarters per acre, at $32 \mathrm{~s}$.

24000

Expences

15950

Profit

$80 \times 50$

\section{OAts.}

\section{Expences.}

Seed, 5 buhels, per acre, at 2s. $6 \mathrm{~d}$. 3150

Weeding, at 2s. 6d.

500

Mowing, at 1s. 6d. a - 3150

Raking, at $2 \mathrm{~s}$.

Hands to get in

500

Threfhing 250 quarters, at Is. 3 d.

300

Rent, \&c.

15126

Wear, \&c.

62100

800 


\section{IRich and iReipectable.}

Produce.

L. S. 6.

Fifty acres, yielding five quarters, per acre, a sl. if fold at a proper time

25000

Expences

$\circ$

$134 \quad 2 \quad 6$

Profit

$115 \quad 17 \quad 6$

A general View of the Profits for the feven Years.

The eighth year thould lie fallow, to tenew the ground; therefore deduet the rent, \& cc. and wear and tear, \&c, of this year

$70 \quad 10 \quad 0$

964 10 6

964l. Ios. left profit in eight years, is at the rate of 1201 . IOs. per year. This, deducted from 4251 . the amount of the family expences, exclufive of the 7 s.l. to be laid up, p. 29, leaves 3051 . Ios. the total expence of keeping the family, \&rc. 


\section{Dhretuations.}

All lands will not yield the fame courfe of crops; but the produce in feven years will be nearly the fame.

I have fuppofed the ground to be tolerably good, and a particular attention to be paid in keeping it clean, well dreffed, and in good tilth: for this purpofe no ftraw is to be fold off the farm but wheat ftraw. It is all to be converted into fodder and dung.

If the farming fervant can be fpared at times, he may threfh much of the grain himfelf; this will be a faving: and there are fill many advantages to be reaped, if a man will enter into the fpirit of farming, from a neighbouring common, in breeding theep, bringing up heifers, \&c. and keeping geếe.

In fhort a tolerably good farm will, upon an average, produce, with good management, 3os. or 405 . per acre, free of all expences.

The price that corn bears, will often make an alteration in the profits of a farm; but I have fet it at a medium price.

If you winh to keep dogs, I will fuppofe the game you kill to pay the expence of them. 


\section{踏b and ZRefuectable。}

TO fuch as win to keep a few nheep, the following Eftimate will be acceptable.

Fine large eives with lamb may be bought in at Michaelmas, at about 22s. each, which, in the July following, will fell again for

The lamb will then fell for E. 110

The wool of the two, fhorn before fold, will fell for about $-170$

$\circ \quad 4 \quad 6$

Deduct the firft coft

2126

Leave profit

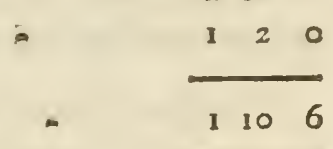

\section{Dbreruations.}

It will take about an acre of grafs to fatten five theep; but, where grafs is not plentiful, they may be fed on ftubble till Chriftmas, then on turneps till May-day; next on rye, and then on clover till fold. No meadows will do for Theep in the winter, that are wet enough to let them fink up to the firft joint of their legs: it will rot them.

Note. An acre of turneps will feed too theep for the fpace of ten days, or about eight from Chriftmas-day to May-day.

N. B. Dung of theep, when folded upon land, for the richnefs of the manure, is equal in value to the profits arifing from the fale of them. 
The principal Implements neceffary for a fmall Farm, are,

A waggon, and a harnefs for ditto.

A broad-wheeled cart, and a harnefs for ditto.

- A plough,

A pair of large harrows.

A pair of fmaller harrows.

A roller.

A winnow.

A feed kit.

Shovel, rakes, meafures, facks, fieves, \&rc. And the whole may be bought new for about 601 .

If a gentleman does not underftand farming, he may foon acquire the knowledge from a clever fervant*.

\section{Jamily Eftimates.}

IN the following eftimates, I have not pointed out what a father of a family ought to lay by annually, as a provifion for his wife and children. When he knows what his expences will be, his income will naturally tell him what he can fave. Suffice it to fay, that 751. a year, put out to inzereft at five per cent. will, in 20 years, produce 25001 . of courfe, double the fum will produce $5000 l$.

* TRUSLER's Practical Hufbandry, an octavo volume, price, 3s. 6d.' fold by R. Baldwin, in Pater-nofter-row, will let him readily into the whole bufinefs of farming. It is a clear, soricife work, and wcll calculated for this purpofe. 


\section{Zich and laefuectable.}

No. I.

An Eftimate of the expences, which a family, confifting of a wife, four children, and two rnaid-fervants, may enter into, who can afford to fpend 330l. a year, fuppofing every thing to be purchafed.

Weekly.

E. s. d.

Bread for 8 perfons, Id. per head daily* $\quad 0 \quad 4 \quad 8$

Butter $6 \mathrm{lb}$. on an average at $9 \mathrm{~d}$. per $\mathrm{lb}$. $\quad 046$

Cheefe 3 lb. at $5 \mathrm{~d}$.

$\circ$ I 3

Roots, herbs, fpices, and the decoraments of the table

$\circ 36$

Meat or firh, 3 quarters of a pound each, at 5 d. per $1 \mathrm{lb}$.

0176

Milk, one day with another, 2d.

- 12

Eggs

Flour

- 04

- 12

Small-beer, at 10s. per barrel, 12 gallons 034

Strong-beer for family and friends $\quad 0 \quad 18$

Tea 2s. and fugar 3 s.

050

Candles $4 \mathrm{lb}$. take the fummer and winter together at $g \mathrm{~d}$.

$\circ 30$

Coals (two fires in winter, one only in fummer; 2 bufhels for parlour fire for 8 months, 3 burhels for the kitchen all the year, about 5 chaldrons, at 11.16 s. per chaldron $)+a$ :

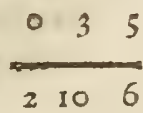

* Suppofing bread at a moderate price.

+ Frugality in this article, as well as in all others, muft be ufe?. 


$$
\text { Brought on } \begin{array}{rrr}
\text { L. s. } & d \text { s } \\
2 & 10 & 6
\end{array}
$$

Soap, ftarch, blue, and wafhing at home and abroad

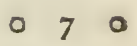

Thread, needles, pins, tapes, and all forts of haberdafhery

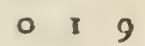

Sand, fullers-earth, whiting, brick-duft, fmall-coal; \&c.

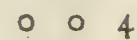

Repair of furniture, table linen, theets, and all utenfils, at

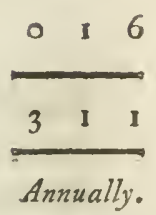

31. Is. 3-halfpence per week is per yeap $\quad \begin{array}{llll}158 & 18 & 6\end{array}$

Cloaths for the mafter, of all kinds is 0 .

Ditto for the miftrefs - $\quad 1500$

Ditto for four children, 61. each : 2400

Lying-in expences 10l. (fuppofe once in two years) $\quad 500$

Pocket expences for the mafter, including letters, 4s. per week - $\quad 108$ o

Ditto for the mitrefs and four children, half the money - $\quad-\quad 540$

Phyfic and occafional ilinefs, on an average 500

Shaving, hair-cutting, and cleaning thoes 2100

Schooling for the children - 800

Wages of two maid-fervants - 1200

Standing rent and taxes about - 5000

Entertainments for friends - 1000

Sundries, for wine, pleafure, \&cc. fuppofe for even money - $\quad 8196$ 


\section{ZRich) and Re[pectable.}

N. B. If this family lives in the country, in rent and fervants wages above 201 . a year may be faved: if they live in London, and take in lodgers, they may ftill ftand at lefs rent than in the country. It is impoffible to afcertain the exact expence of every article, as fome families may like to indulge in fome one certain thing more than others; but what is faved in one article, may be fpent on another.

For every child lefs than four, may be fubtracted from the above 3301 . according to the foregoing eftimate, and for every child more than four, muft be added as follows: $f$.

Maintenance for each child per anmum _ 20

Cloaths - $\quad$ - $\quad$ - 6

The tax is not reckoned

If they keep but one maid-fervant, by the foregoing eftimate, fubtract 24l. annually; if three are kept, add 24l. as follows: $f$.

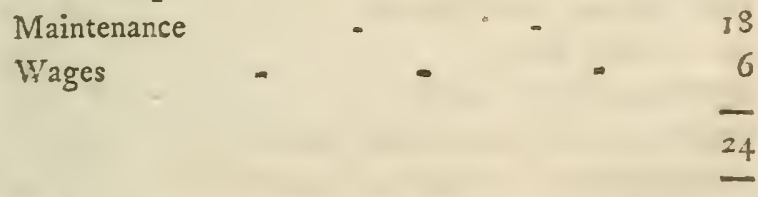

The difference between a maid-fervant and a man-fervant, if out of livery, will be only in the wages, about 41 . or 51 . if in livery, the addition of the livery about 5 l. befides the'tax.

No. II. 
The following eftimate is given more as a matter of curiofity than any thing elfe, to thew how much fuch a family may fave upon a different plan, and what the expences of houfe-reeping amount to.

Lodging and board for the man and his wife in

Annually: f. s. $d$.

a decent family, in town or country, with

a table equal to that in No. I.

6000

Tea and fugar, 2s. 6d. per week

6100

Coals and candles

Wathing abroad

500

Shoes cleaning, and barber, 10s. per quarter

To the fervant of the family

Three childreu at boarding-fchool, at 161. per

a)num

6100

200

110

Extra expences for books, pocket-money, \&c. 600

Infant at nurfe, at 4 s. per week $\quad-\quad 1080$

Extra expences for ditto - - 100

Cloaths for the mafter - $\quad 15 \circ 0$

Ditto for the miftrefs - $\quad 150$,

Ditto for the three children - $\quad 1800$

Ditto for the infant - $\quad 300$

Apothecary for the whole - $\quad-500$

Pocket expences for the man and wife - 1000

Entertainments for friends, none expected 000

Sundries, for wine, pleafure, \&c. as in No. I, $\quad 8196$

Lying-in expences, as in No. . $\quad$ - 500

f. $\overline{22686}$

Thus it appears, that above 100l. a year may be faved by this different plan of living. 
No. III.

An Eftimate for a man and his wife living comfortably and genteely in the country, with two fervants.

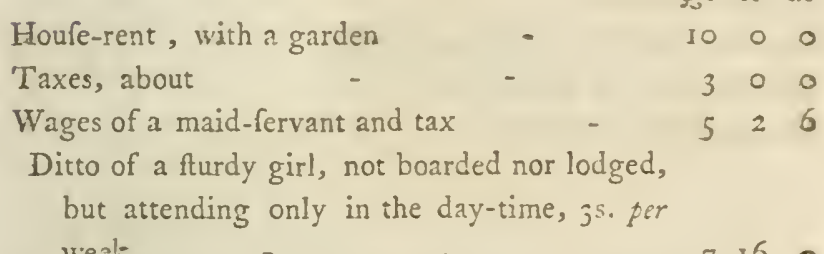

Houfe-rent, with a garden
Taxes, about
Wages of a maid-fervant and tax
Ditto of a fturdy girl, not boarded nor lodged,
but attending only in the day-time, $j^{5 .}$ per

Houfe-rent, with a garden
Taxes, about
Wages of a maid-fervant and tax
Ditto of a fturdy girl, not boarded nor lodged,
but attending only in the day-time, js. per

Houfe-rent, with a garden
Taxes, about
Wages of a maid-fervant and tax
Ditto of a fturdy girl, not boarded nor lodged,
but attending only in the day-time, $3^{\text {s. per }}$
week

Annually. S. s. 4.

Cloaths and pocket-money for the man

Ditto for the woman - $\quad$ - 10 -

Bread for three perfons at is. gd. per week $\quad 4$ II 3

Butter 2lb. per week, at Sd. - - 398

Cheefe Ilb. per week $\quad-\quad$ - $\quad$ I 18

Meat, fith, or fowl, $3 \mathrm{Ib}$. weight a day, on an average, at 5 d. per lb.* - - $\quad 2216 \quad 3$

Vegetables from the garden; looking after the garden by the year - $\quad 200$ Oil, vinegar, and other decoraments of the table, gd. per week

Tea and fugar 4s. por week

Small-beer and ale, brewed at home, allowing a quart of ale to be given daily away, $2 s .4 \mathrm{~d}$. per week

Wilk and cream, ;d. per week Soap and ftarch, Sic. 18. per week Eggs 4d. per week; flour 7 d. 618 1105 2120

\section{Carry forward $\overline{10+16 \quad 1}$}

* Poultry is never above $5 \mathrm{~d}$. per $\mathrm{lb}$. in the country; by the fea-coaft, fin is very cheap; and where filh $i s$ cheap, meat is proportionably fo. See Note, p. 35. 


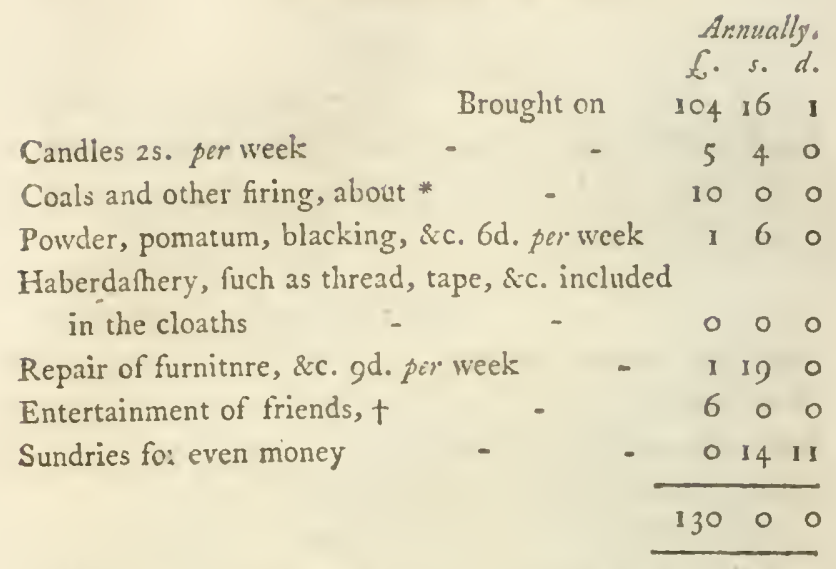

Let us now fee what it would coft him to live equally well in London.

No. IV.

Houfe-rent and taxes, or lodging $\ddagger$ Wages of two maid-fervants and taxes - 14100 Cloaths and pocket-money for man $\$ \quad-\quad 15 \quad 0 \quad 0$

\section{Carry forward}

* in woody countries, the expence of firing will be lefs, and much more fo in parts neighbouring to coal-mines; and where both wood and coals are dear, peat perhaps may be got: the Dutch in general burn it in the brighteft ftoves. Coppers hould have no ftove under them to burn coals; but they fhould be heated with furze cut from the Common : a large copper ftove will burn as many coals as a kitchen range.

+ This article is not under-rated, as, when the entertainments are returned, there is fome faving at home.

I If he takes a houfe, he mult be troubled with lodgers, unlefs he ftands at a great rent.

\$ There are more temptations in London to fpend noney; and, as they are always feen, they mult appear bettcr. 


\section{tiich and Refpectable.}

Annualin.

f. s. d.

Ditto for woman

Bread for four perfons

$7+100$

Butter ${ }_{3}$ lb. per week, at 1 dod.

1200

Cheefe 2 lb. per week

Brought on

120

Meat or fifh, 4 lb. a day, at 5 d.

Extra for fowls occafionally, 23. a week - 5 - 5 o

Vegetables, 2s.6d. a week - - 6100

Fruit, if they eat any, 1s. a week $\quad z 120$

Oil, vinegar, \&c. - - I 190

T'ea and fugar, 4s. a week - . 1080

Small-beer at ifs. a barrel, about 9 gallons a week 920

Porter and ftrong-beer for the mafter's table,

(none to give away) $7 \mathrm{~d}$. per day - 101211

Milk and cream, 2d. halfpenny per day - 452

Soap; ftarch, \&c. 2s. 6d. a week, almoit double

the wafhing in town - $\quad .6100$

Eggs and flour - $\quad 2 \quad 278$

Candles'3s. a week - - - 7160

Coals, and other firing - 1000

Powder pomatum, blacking, \&c. - 160

Repair of furniture, \&ic. - $\quad$ - 190

Entertainment of friends - - 600

Sundries, for even morey $\quad 1127$

Expences in the country life $\begin{array}{r}219100 \\ 13000 \\ \hline 89100\end{array}$

Here is a difference of 891 . Ios. and many indulgencies loft, by a town life.

No. V. 
No. V.

A man and his wife in town, with four children and one maid-fervant, whofe trade brings in clear but 200l. annually, muft conform as follows:

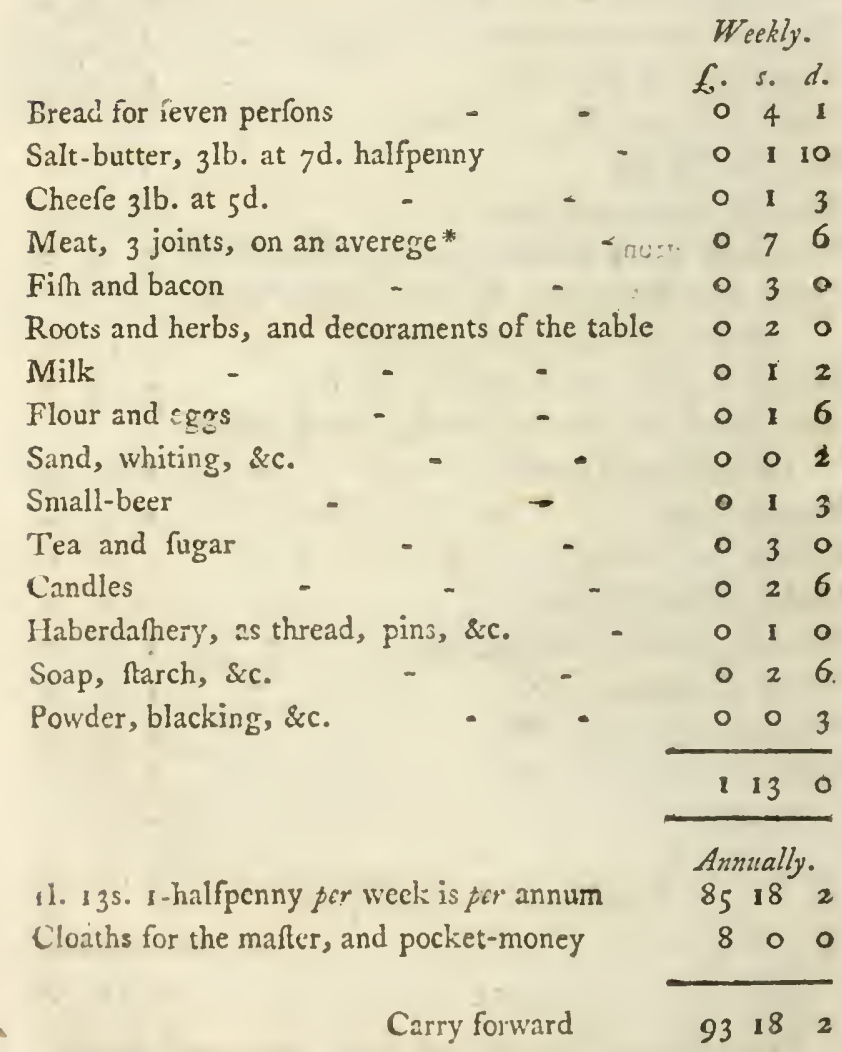

* Some joints will coft more than half a crown ; but many articles 


\section{lRich and Refpectable.}

Annzally.

Brought on $\quad \begin{array}{llr}\text { L. } & \text { s. } & \text { d. } \\ 93 & 18 & 2\end{array}$

Cloaths and pocket-money for the miltrefs

Ditto for four children

Maid's wages

600

160

Boy to go on errands, 6d. a day。 (not boarded)

500

Coals, two fires in winter, one in fummer, five

chaldron, at 1l. 14s. - - 8100

Schooling for the children - - $3 \circ 0$

Phyfic for the family, on an average $=200$

Entertainment for friends - $\quad 4 \quad 0 \quad 0$

Expenses of lying-in are chiefly defrayed by the prefents of goflips (fuppofe 51 . extra, once in

two years) - $\quad-\quad 2100$

Rent and taxes, exclufive of lodgers (though

many contrive to live rent-free) - 1500

Repair of furniture, utenfils, \& c. $\quad-\quad 200$

Expences of trade with cuftomers, travelling

charges, Chriftmas-box-money, pens, paper,

letters, Sic. fuppofe for even money

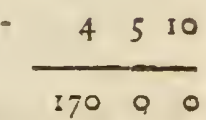

He may then lay by for the children, or lay out

on other purpoles

3000

20000

It is impofible to give eftimates to fuit every family; but it will be very eafy for any one to

articles that will go through fuch a family, may be bought for lefs : as half a calf's head for 1s. 3 d, a bullock's heart for 1s. 4d. \&x. 
regulate his expences by thefe; adding or deducting, for a child or fervant, more or lefs, or for the difference of houfe-rent, certain indulgences, or variation in the price of provifions. If every miftrefs keeps a weekly book, and has an eye upon her fervants; thould the exceed her expences one week, the may retrench them in another.

I muit repeat here, that 1 5l. or 201 . per cent. may be faved in many articles by buying things at the firft hand, and paying ready money where it can conveniently be done; befides preventing things being charged a family never had.However, by no.means thould a bill be run up with either butcher, baker, chandler, greengrocer, or milkman.

\section{No. VI.}

The expence of keeping a horfe in the fable in fummer, and at fraw in winter.

A truis of fraw per week Weekly. f. s. d.

Two truffes and a half of hay, at 3l. 3s. per load 044 'Three quarters of a peck of oats per day, at $18 \mathrm{~s}$.

a quarter, that is,

Man to look after him
- 31

- 26 


\section{iRiçb an๖ 1Refpectable.}

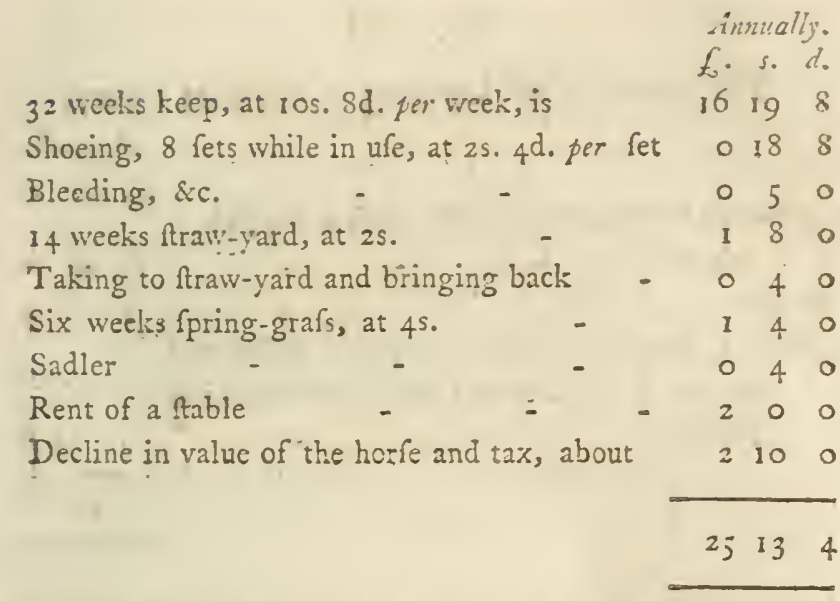

The addition of a one-horfe chaife will be as follows:

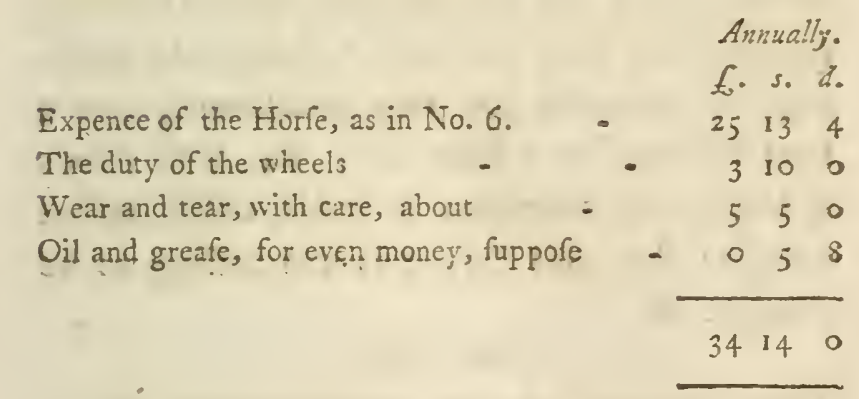

Turnpikes and expences on the road muft alfo be thought of.

No. VII. 
The expence of keeping a horfe at livery.

32 weeks hay and corn (three feeds a-day) at

Hoftler

Shocing, bleeding, Atraw-yard, grafs, fadler, and decline in value of the horfe, the fame as in No. VI.

\begin{tabular}{rr}
$6 \quad 138$ \\
$24 \quad 10 \quad 8$ \\
\hline
\end{tabular}

So that it is cheaper to keep him at livery than not, provided he be kept where the beaft will have juftice done him; and ftable-keepers will be found that will give the chaife a ftanding gratis, if they keep the horfe. Indeed, by keeping him yourfelf, you may occafionally fave a feed of corn, or a little hay; for, if he ftands at livery, no deduction is made, unlefs abfent a night: but this faving is too trifling to be thought of.

No. VIII.

The expence of keeping a chariot or poit-chaife, or pair of horfes, in your own table.

Annually.
Seven loads and a half of hay, that is, five trufies
a week, and ten trufles allowed for wafte, at
3l. 10s. a load
Carry forward $\frac{2410 \quad 0}{24300}$ 


\title{
Ricb and Refuectable.
}

\author{
Annually. \\ L. s. $d$. \\ Brought on $2410 \quad 0$
}

Two truffes of ftraw fer week, or about three loads, at 25s. per load

20 quarters 2 bufhels of oats, at nine buthels to

3150

the quarter: this is allowing each horfe a peck a day, at $18 \mathrm{~s}$. per quarter. (Beans are not neceflary, unlefs very hard worked) is 50

Rent of fable and coach-houfe

Blackfmith for Moes, at 2s. 4d. per fet; each

horfe 18 fets, on an average

440

Phyfic

- 60

Oil and greafe, 1s. a week

2120

Wear and tear of carriage, and repair of wheels

and harnefs, and painting once in two years, about

Decline in value of the horfes and tax, about

Coachman's wages and tax

$200-0$

Board-ivages, or board at home, much the fame

1100

Livery, about

1750

Duty on wheels

1800

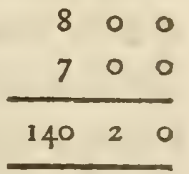

Expences ftanding at livery.

The two horfes 12s. per week each (chariot ftand-

$\begin{aligned} & \text { ing included) } \\ & \text { Hoftler will expect }\end{aligned}$
Expence of keeping them yourfelf, other articles being the fame

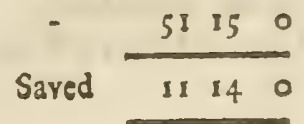


There may alfo be a further faving in hay and corn, by being out occafionally, and a reduction of the prices at market.

The price of a job, for a pair of horfes and a

Annually.

f. s. $d$

coachman is now 12l. a month, though

fome will let them by the year, for 101 .

fuppofe 101 . that is per year. - $\quad 120 \quad 0 \quad 0$

If the carriage is hired alfo, they will expect,

40s. a month more

Coacliman will expect a prefent of

Ditto great-coat, hat and tax

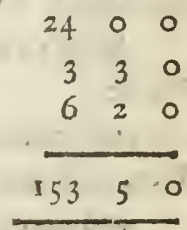

In this cafe, if they are upon the road, the coach-mafter expects an addition of 2s. a night, every night they are out, to pay extra expences of hay, corn, and fervants keep; but I know fome gentlemen who keep a job, and pay rool. a year only, for coachman and horfes, giving the ufe of a ftable when in the country. At this rate, it is the cheapeft method of keeping a carriage. Thus,

Job horfes and coachman

Prefent to coachman

Annually.

Great-cost, hat and tax

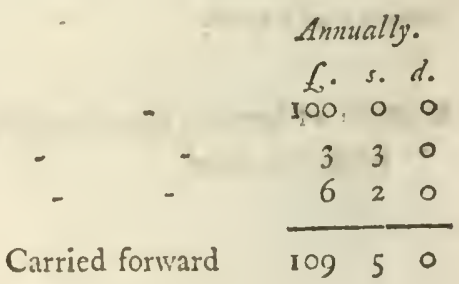




\section{QRich and IRerpectable.}

Duty on wheels

Brouglit on

Anntually.

E. s. $d$. 10950

Oil and greaíe, as in No. 8 .

700

Wear and tear of carriage, \&c. as in No. 8.

2120

2000

$138 \quad 17 \quad 0$

By this eftimate, the expences appear to be lefs than keeping them in your own ftable. To be fure, you have none of the coachman's fervice but that of driving; but then, on the other hand, you are not liable to lofe the ufe of your carriage by accidents attending the horfes. Indeed, to keep a chariot and a pair of horfes properly, three horfes thould be kept for the purpore; and this advantage you have by hiring job-horfes.

N. B. Thofe who win to fee further eftimates appropriated to different fituations in life, I will refer to the London Advifer and Guide, price 3s. a ufeful work lately publihed by $D_{R}$. TRUSLER, containing every information neceffary to perfons living in London, in order to enable them to enjoy fecurity and tranquility, and conduct their domeftic affairs with economy: with an abitract of all thofe laws which regard their protection againft the infults, frauds, impofitions, and accidents they are there liable to. This work treats fully on near five hundred different fubjects. 
The following ufful BOOKS may be had at No. I4. Red-Lion-Street, Clerkenruell: and of all the Booksellers in Town and Country.

Calculated chiefly for Yeung PEOPLE.

\section{By the Rev. Dr. T R U S L E-R.}

I. DRINCIPles of Polteness, Parts $I$. and II. L $15^{\text {th }}$ Edition, price 3 s. half-bound. Containing every infruction neceflary to complete the Gentleman and Man of Farhion, to teach him a knowledge of life, and make him well received in all companies. For the improvement of youth, yet not bencath the attention of any. Part II. is addreffed to and calculated for young LadiesiThis book is adopted as a fchool-book in the firft academies in Europe, and has been tranflated into all European Languages. A French Edition may be had price 5. fewed, in 2 volumes.

II. A COMPENDIUM Of USEFUL KNOWLEDG, price 3s. half-bound, containing a clear and concife account of every thing a young perfon ought to know: fich as are acquainted with the contents of this book will be able to talk on all the general topics in life.

III. The Distinction between Worns efteemed SYNonimous in the Englifh Language, price $3^{\text {s. }} 6$ d. fewed, fecond Edition, in one volume, $12 \mathrm{mo}$. with im. provements and many additions; ufeful to thofe who would either write or fpeak with propriety and elegance.

IV. Poetic ENdings, or a Dictionary of $R$ HYMES, fingle and double, comprifing nearly all the words in the Engliin Language, price 2s. 6d. fewed.

V. An English Accidence; or, Abstract of GrasMAR, calculated for thofe who wilh to write and fpeak 


\section{U S E F U L B O O K S.}

Speak correaly, without making grammar a fudy; with rulcs for reading profe and verfe, by the Rev. Dr. TRUSLER. Price is.

VI. An ABstract of the BOOK of COM:10N PRAYER; or, a PSALTER, wherein the emphatical words are marked and the language fo pointed, as to render it almolt impoffible to be read with the leaft attention, but with propriety. For the ufe of fchools and thore who wifh not to be burthened at Church with a larger book, as it will lie in the waiftcoat pocket, price $2 \mathrm{~s} .6 \mathrm{~d}$. bound in black and gilt, with the finging pralms added, 2s. Iod. All parts that are neceffary for taking to Church are here inferted, and no other except the Catechifm.

VII. The Sublime Reader; or, the Parts of the SERVICE, appropriated to the MINISTER; printed as No. VI. above. Second Edition, price 2s. With notes of general ufe.

VIII. The First Four Rules of Arithimetic, price is. So fully explained as to be learned without the help of a mafter, which is not the cafe with any book of arithmetic extant.

As nine tenths of the people, particularly women have no occafion to learn any more than the Firft Four rules, and have it not in their power to procure a mafter, they will find this work fufficiently adequate to the purpole of inftrueting them; each rule being clearly and fully explained even to the capacity of girls; and with the following book, called

IX. FAMILY TABLEs, price 3s. (being a collection of ufeful tables, accurately framed for the various purpores of life) they will find a knowledge of more than the firft Four Rules of arithmetic unneceffary.

X. A Careful ABridgement of Blackstone's COMMENTARIES, with the Law terms extlained throughout. quarto, price 15 s. boards.

XI. 


\section{USEFUL BOOKS.}

XI. Chronologx; or, the Hiftorian's VADE MECuM, 2 vols. 7 s. bound. The twelfth Edition, with great Additions, and a lift of the County Sheriffs from 1760 . In this work every event in Ancient and Modern Hiftory is alphabetically recorded, with the date affixed, alfo the rife and improvement of the Arts and Sciences, and the times. when all great men lived.

XII. An ABRIDGEMENT of the above for the pocket, price 1s. 6d.

The following are cliefly calculated for the ufe of Perfons living in the Country.

By Dr. T R U S L E R.

I. The Country Lawyer, price 3s. being a fum. mary of all thofe Acts of Parliament, with the Opinion of the Courts thereon, which perfons living in the Country have continually occafion to refer to :-Such as

$\begin{array}{lll}\text { Landlords, Tenants, } & \begin{array}{l}\text { Dogs, } \\ \text { Clergy, }\end{array} & \begin{array}{l}\text { Horfes, } \\ \text { Carriages, }\end{array} \\ \text { Commons, } & \text { Parih-Officers, Shops, } \\ \text { Trefpaffes, } & \text { Highways, } & \text { Windows, all } \\ \text { Nufances, } & \text { Servants, } & \text { theTaxAEts, \&c, } \\ \text { Game, } & \end{array}$

Noт E. Every fubject is here fully and accurately treated. more fo than in any one book extant, and all the laws, \&c. refpecting the Clergy, more at large than in any other publication.

II. Practical Husbandry, or the method of Farming with a certainty of Gain, as practifed by all judicious farmers in this Country; the refult of many Years experience; by Dr. TRUSLER, of Cobbam, Surrey. Second Edition, price 3s. 6d. fewed.

In this work the plain bufinefs of Farming is fet forth, without 


\section{USEFUL BOOKS.}

without either theory, fpeculation, or experimental Enquiry : a variety of Eflimates of the profits of different crops are given, from Minutes kept, and the method of meafuring Timber laid down.

This book demonftrates to a moral certainty, the clearing of 4 ool. a year, on a farm of 150 acres of Land.

III. Elements of Modern Gardening; or, tho Art of laying out of PLEASURE GROUND, and embellihing the views round about our houfcs, price 23 .

I. An Historical and Political View of the Ancient and Prefent State of the COLONY of SURINAM, in South America; together with the fettlements of Demerary and Iffequibo, taken from the Dutch by Lord Rodney; with an account of their productions for twenty-five years paft. Price 3 s.

By one who lived there ten Yẹars.

Tranflated from the French, by Dr. JоH. TRESLER.

II. A Descriptive Account of the principal ISLANDS in the SOUTH SEAS, in one volume 8vo. price 5s. boards; giving a full detail of the Religion, Gorernment, Cuftoms, Manners, \&-c. of the Inhabitants, from the firt difcovery to the prefent time; containing every thing entertaining and inftructive to the general reader, to be met with in Mendana, Le Maire, Schouten, De Quiros, Tafman, Bougainville, Cook, Parkinfon, Fourneau, Forfter, and cthers, who have failed into that part of the world; with an account of the Country of Kamichatka. By the Rer. Dr. TRUSLER.

III. Luxury no Political Evil, but proved to be neceffary to the prefervation and well-being of States. Price zs. By Dr. TRUSLER.

IV. 


\section{USE H U BOOKS.}

IV. Leetures on the Gravid Uterus and the Art of Midwifry. Price 2s. By the late Dr. William HUNTER. With the medical terms explained, for the benefit of female pråtioners. Taken in Short Hand by one of his Pupils. It having been faid, that Dr. Hunter's revifion of this tract, was on condition that it fhould not be publifhed; the Editor begs leave to fay, no fuch condition was ever made or enjoined.

V. An Elegiac Poem on the Fears of Deatm, 4to. Price is. 6d. By the Rev. Dr. TRUSLER.

VI. The Ecosomis $\mathrm{T}$, price 1s, being eftimates of Domeftic Expences; adapted to all fituations of life, and hewing what expences a family may with prudence enter into, confiftent with their incomes.

VII. LOR D VER ULAM'S HISTORY OF HENRY VII. firft written in 1616. now penned in modern language, but without lofing the fpirit of the original. By the Rev, Dr. 'TRUSLER.

This Hitory has been allowed to be the beft extant of that reign, and the uncouth language of the times.when it was firft compiled, makes this Edition acceptable, being printed as a companion to LYTTELTON'S HENRY II. price bound $6 \mathrm{~s}$.

X.' MODERN TIMES; or, the ADVENTURES of Gabries. OUTCAst, firft publifhed under the patronage of the Literary Society, in 3 vol. $12 \mathrm{mo}$. price gs. fewẹd, tho third edition.

Thofe who have a true relin for fatire, and like to fee the world as it $\vdots$, will be highly entertained by a perufal of this work. It is written in imitation of Gil Blas; is replete with humour, and contains many entertaining anecdotes of characters now living, and in falhionable life. 


\section{USEFUL BOOK S.}

The following are fome of the interefting fcenes it defcribes, and characters it expofes:

Pedlars, inn-keepers, and ftage-coachmen.

School-mafters, puffers at auctions, and brokers.

Made-up auctions, trading juftices, and Newgate folicitors.

Women of the town, thief-takers, and night cellars.

The arcana of a newfpaper office.

Priggin parfons, pedants, and regifter offices for the clergy.

Lecturers, pimps, players, and ftatefmen.

Procureffes, falhionable life, and tonifh vifiting.

A St. Giles's lodging, fmugglers, and marauders.

Privateering, bailifis, and fpunging ${ }_{T}$ houles.

Regifter-ofrices, thopping, and arts of fradulent tradefmen.

The credulity and ignorance of men and women of fashion.

Phyficians, apothecaries, and men-midwives.

The college of phyficians, and their licentiates.

Strolling players, quakers, and kept miftrefies.

Authors, bookfellers, acd hireling writers.

Libellers, reviewers, ftock-brokers, and place-mongers.

Attornies, barrifters, and affidavit-makers.

Falfe-mourning, duelling, witchcraft, and the pride of the Irifh.

Members of Parliament, cabinet-council, minifters, \&c. Sc.

The whole blended with an entertaining ftory carried through the three volumes, and calculated to thew the rifing generation the arts and iniquities of the world.

2ui capit, ille facit. 




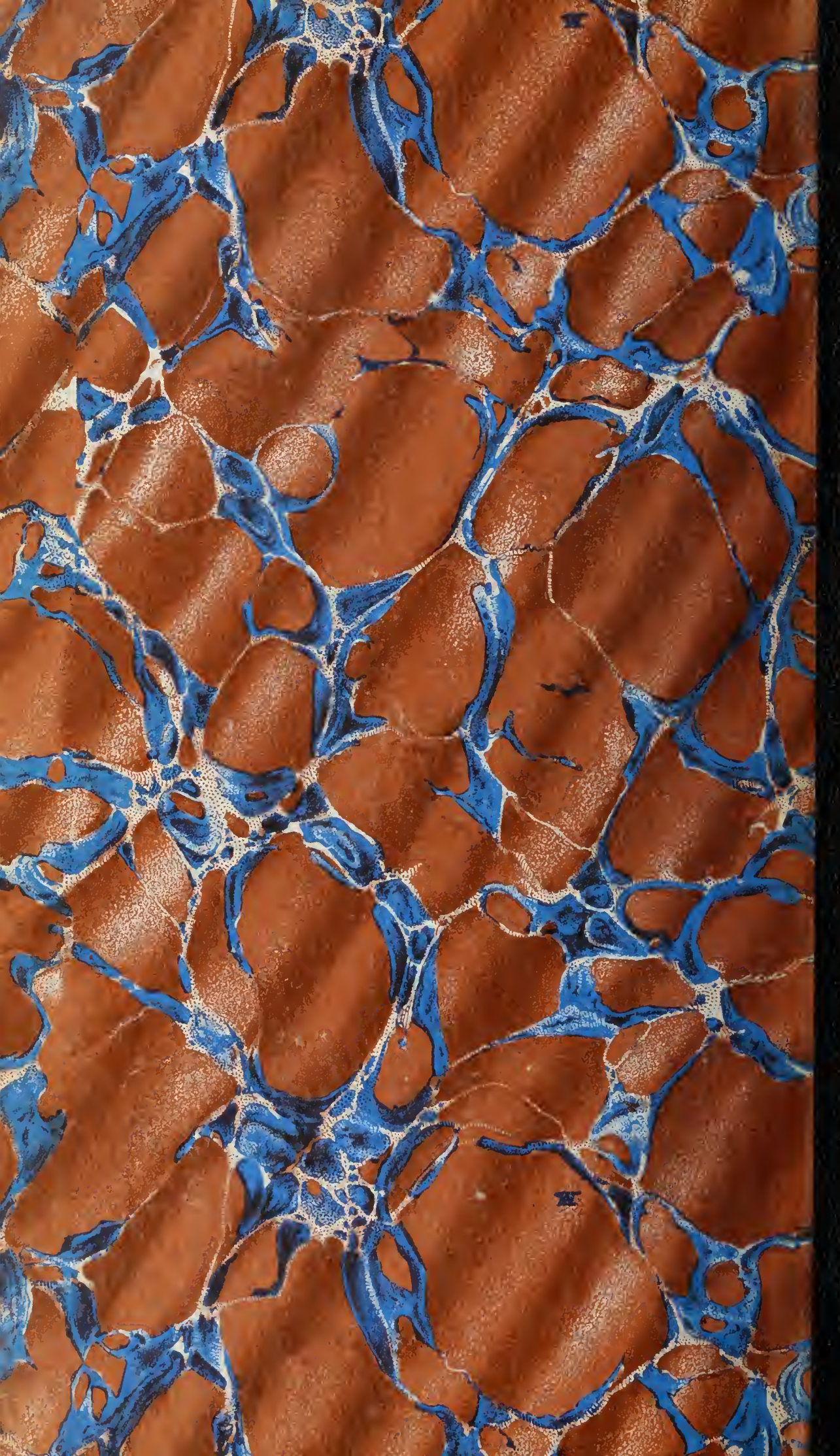

